DOI: $10.19195 / 0137-1134.118 .4$

\author{
MARIUSZ JABŁOŃSKI \\ ORCID: 0000-0001-8347-1884 \\ Uniwersytet Wrocławski
}

\title{
MIEJSCE PAŃSTWOWEJ INSPEKCJI PRACY W SYSTEMIE ORGANÓW PAŃSTWA - WNIOSKI DE LEGE LATA I DE LEGE FERENDA
}

\begin{abstract}
Abstrakt: W opracowaniu autor koncentruje się na określeniu pozycji ustrojowej Państwowej Inspekcji Pracy. Analiza dotyczy obowiązującej regulacji konstytucyjnej (Konstytucji RP z 2 kwietnia 1997 roku) oraz regulacji ustawowych. Ocena wybranych rozwiązań ma na celu ustalenie charakteru działalności Państwowej Inspekcji Pracy, jej umiejscowienia w ramach konstytucyjnej systematyki organów oraz znaczenia efektów realizacji przez nią zadań z punktu widzenia ochrony konstytucyjnych wolności i praw jednostki.
\end{abstract}

Słowa kluczowe: Państwowa Inspekcja Pracy, konstytucja, wolności i prawa jednostki, niezależność, pozycja ustrojowa, zasada podziału władz, gwarancje

\section{KONSTYTUCYJNE ZNACZENIE „PRACY” I OBOWIĄZKU JEJ OCHRONY PRZEZ PAŃSTWO}

W treści Konstytucji RP z 2 kwietnia 1997 roku brakuje jakiegokolwiek odwołania do terminu ,inspekcja pracy” czy już bezpośrednio do Państwowej Inspekcji Pracy ${ }^{2}$. Nie jest więc możliwe jednoznaczne określenie konstytucyjnych gwarancji, które mogłyby wskazywać na szczególny charakter jej pozycji, kompetencji, a w konsekwencji bezpośrednie powiązanie z pojęciem „władzy publicznej”’3.

1 Konstytucja RP z 2 kwietnia 1997 roku, Dz.U. Nr 78, poz. 483 ze zm.

2 Por. krytyczne uwagi T. Liszcz, Państwowa Inspekcja Pracy - strażnik praworzadności w stosunkach pracy, „Kontrola Państwowa” 2006, nr 3, s. 62.

${ }^{3}$ W orzecznictwie Trybunału Konstytucyjnego wskazuje się, że „pojęcia organu państwa oraz organu władzy publicznej nie są tożsame. W pojęciu »władzy publicznej« mieszczą się bowiem także inne instytucje niż państwowe lub samorządowe, o ile wykonują funkcje władzy publicznej w wyniku powierzenia czy przekazania im tych funkcji przez organ władzy państwowej lub samorządowej. Wykonywanie władzy publicznej dotyczy wszelkich form działalności państwa, samorządu terytorialnego i innych instytucji publicznych, które obejmują bardzo zróżnicowane formy aktywności. Wykonywanie takich funkcji łączy się z reguły, chociaż nie zawsze, 
Brak takiego bezpośredniego umocowania konstytucyjnego nie oznacza jednak, że nie istnieją podstawy dla jasnego i czytelnego powiązania konkretnego, wyodrębnionego prawnie i wyspecjalizowanego kompetencyjnie, organu z zasadami i wartościami konstytucyjnymi.

Warto bowiem podkreślić, że obowiązująca Konstytucja RP wielokrotnie odwołuje się do terminu ,praca"4, nadając mu charakter jednej z podstawowych wartości polskiego porządku konstytucyjnoprawnego. Nie może być inaczej, jeżeli weźmiemy pod uwagę, że ustrojodawca z jednej strony podkreśla konieczność wdzięczności „,naszym przodkom za ich pracę” (preambuła) ${ }^{5}$, z drugiej zaś stwierdza, że:

— „Praca znajduje się pod ochroną Rzeczypospolitej Polskiej. Państwo sprawuje nadzór nad warunkami wykonywania pracy (art. 24 Konstytucji RP)”, co identyfikuje się bezpośrednio z uznaniem pracy i obowiązku jej ochrony za podstawowy element treści ustroju społecznego i gospodarczego RP';

— „Kobieta i mężczyzna mają w szczególności równe prawo do kształcenia, zatrudnienia i awansów, do jednakowego wynagradzania za pracę jednakowej wartości, do zabezpieczenia społecznego oraz do zajmowania stanowisk, pełnienia funkcji oraz uzyskiwania godności publicznych i odznaczeń" (art. 32 ust. 2 Konstytucji RP, czyli jedna z zasad przewodnich konstytucyjnej regulacji wolności i praw człowieka i obywatela).

Jednocześnie w dalszych postanowieniach dotyczących konstytucyjnych wolności i praw jednostki (wolności i prawa polityczne, ekonomiczne, socjalne i kulturalne) gwarantuje się poszanowanie:

z możliwością władczego kształtowania sytuacji jednostki. Dotyczy to obszaru, na którym może dojść do naruszenia praw i wolności jednostki ze strony władzy publicznej” — wyrok TK z dnia 4 grudnia 2001 roku, SK 18/00.

${ }^{4} \mathrm{Na}$ temat praw pracowniczych i standardów międzynarodowych zob. P. Kuczma, Prawa pracownicze, [w:] Realizacja i ochrona konstytucyjnych wolności i praw jednostki w polskim porzadku prawnym, red. M. Jabłoński, Wrocław 2014, s. 562 n.

5 Odwołanie to ma na celu podkreślenie pracy przeszłych pokoleń jako fundamentu, na którym opierało się i opiera funkcjonowanie państwa polskiego. Niewątpliwie chodzi też o podkreślenie roli pracy w budowie podwalin państwa polskiego, jak również zachowania jego ciągłości nawet $\mathrm{w}$ okresie zaborów.

${ }^{6}$ Choć szkoda, że przepis ten nie pozwala na wyprowadzenie prawa podmiotowego, zob. więcej S. Jarosz-Żukowska, Charakter i znaczenie wolności i praw jednostki wyrażonych $w$ rozdziale I Konstytucji RP, [w:] Wolności i prawa jednostki w Konstytucji RP, t. 1. Idee i zasady przewodnie konstytucyjnej regulacji wolności i praw jednostki w RP, red. M. Jabłoński, Warszawa 2010, s. 109, 117 i 120. Trybunał Konstytucyjny zauważył, że ,analiza niektórych innych przepisów rozdziału I Konstytucji prowadzi do wniosku, że wynikać z nich mogą nie tylko zasady prawa w sensie przedmiotowym, ale i prawa podmiotowe. Jednak znajdują one z reguły swoją konkretyzację w tej materii w rozdziale II. Taki związek dostrzec można między art. 24 Konstytucji z jednej, a art. 65, art. 66, art. 67 ust. 1 i art. 69 Konstytucji” - wyrok TK z dnia 29 kwietnia 2003 roku, SK 24/02. 
— wolności zrzeszania się pracowników i prawa do strajku (art. 59 Konstytucji) 7 ;

- wolności pracy, (ustawowy wymóg definiowania obowiązku pracy), prawa do wynagrodzenia za pracę (art. 65 ust. 1-4 Konstytucji);

— prawa do bezpiecznych i higienicznych warunków pracy (art. 66 ust. 1 Konstytucji);

- prawa do wypoczynku i konieczności ustawowego określenia maksymalnych norm czasu pracy (art. 66 ust. 2 Konstytucji);

- prawa do zabezpieczenia społecznego w razie niezdolności do pracy ze względu na chorobę lub inwalidztwo oraz po osiągnięciu wieku emerytalnego (art. 67 ust. 1 Konstytucji);

- prawa obywatela pozostającego bez pracy nie z własnej woli i niemającego innych środków utrzymania do zabezpieczenia społecznego (art. 67 ust. 2 Konstytucji);

— prawa przysposobienia do pracy (art. 69 Konstytucji) ${ }^{8}$.

Nakłada też obowiązek prowadzenia przez państwo polityki zmierzającej do pełnego, produktywnego zatrudnienia poprzez realizowanie programów zwalczania bezrobocia, w tym organizowanie i wspieranie poradnictwa i szkolenia zawodowego oraz robót publicznych i prac interwencyjnych (art. 65 ust. 5 Konstytucji) ${ }^{9}$.

Konieczne ponadto staje się podkreślenie, że do pojęcia „praca” ustrojodawca odwołał się również w celu zapewnienia szczególnych gwarancji systemowych dotyczących konkretnych grup zawodowych bądź organów oraz organizacji ich reprezentujących, to jest:

7 1. Zapewnia się wolność zrzeszania się w związkach zawodowych, organizacjach społeczno-zawodowych rolników oraz w organizacjach pracodawców.

2. Związki zawodowe oraz pracodawcy i ich organizacje mają prawo do rokowań, w szczególności w celu rozwiązywania sporów zbiorowych, oraz do zawierania układów zbiorowych pracy i innych porozumien.

3. Związkom zawodowym przysługuje prawo do organizowania strajków pracowniczych $\mathrm{i}$ innych form protestu w granicach określonych w ustawie. Ze względu na dobro publiczne ustawa może ograniczyć prowadzenie strajku lub zakazać go w odniesieniu do określonych kategorii pracowników lub w określonych dziedzinach.

4. Zakres wolności zrzeszania się w związkach zawodowych i organizacjach pracodawców oraz innych wolności związkowych może podlegać tylko takim ograniczeniom ustawowym, jakie są dopuszczalne przez wiążące Rzeczpospolitą Polską umowy międzynarodowe.

${ }^{8}$ Na temat praw pracowniczych, zabezpieczenia społecznego, pomocy społecznej zob. P. Kuczma, Prawa pracownicze, [w:] Realizacja i ochrona konstytucyjnych wolności i praw jednostki..., s. 561 n.; idem, Prawo do zabezpieczenia spolecznego, ibidem, s. 595 n.; idem, Prawo do pomocy społecznej, ibidem, s. 619 n.

9 Na temat norm programowych i obowiązków państwa zob. M. Bernaczyk, Pojęcie publicznych praw podmiotowych w świetle Konstytucji RP, [w:] Wolności i prawa jednostki w Konstytucji $R P$, t. 1. Idee i zasady..., s. 265 n.; zob. też wyrok TK z dnia 13 marca 2000 roku, K 1/99, w którym Trybunał przeprowadza analizę treści art. 65 ust. 5 Konstytucji RP. 
— sędziów sądów oraz sędziów Trybunału Konstytucyjnego — gwarancje warunków pracy i wynagrodzenia odpowiadających godności sprawowanego urzędu oraz zakresowi ich obowiązków (art. 178 ust. 2 i 195 ust. 2 Konstytucji);

— ogólnokrajowych organów związków zawodowych oraz ogólnokrajowych władz organizacji pracodawców i organizacji zawodowych — prawo do wystąpienia z wnioskiem do TK (art. 191 ust. 1 pkt 4 Konstytucji).

Szczególne znaczenie ma również wprowadzenie wyłączności ustawowej w zakresie ograniczania wolności pracy (art. 65 ust. 1), prawa do bezpiecznych i higienicznych warunków pracy (art. 66 ust. 1) oraz prawa do wypoczynku (art. 66 ust. 2 Konstytucji $)^{10}$.

Mając powyższe na uwadze, w szczególności zaś wskazanie, że to państwo sprawuje nadzór nad warunkami wykonywania pracy (art. 24 Konstytucji RP), zastanawiające jest, że ustrojodawca nie zdecydował się na skonkretyzowanie, jaki organ (organy) w szczególności uprawniony jest do sprawowania takiego właśnie nadzoru. Wydaje się, że w trakcie przyjmowania kolejnych postanowień Ustawy Zasadniczej zwyciężyło przekonanie, że takie rozwiązanie nie jest potrzebne i uzasadnione okresem transformacji ustrojowej, charakteryzującym się wieloma modyfikacjami modelu dotychczas funkcjonujących organów i instytucji państwowych. Jednocześnie na brak takiej decyzji mogło mieć wpływ przyjęcie rozwiązania, w którym zastosowana w art. 24 Konstytucji formuła „sprawowania nadzoru przez państwo" - a nie kontroli i/bądź ochrony prawnej — różniła się od sposobu klasyfikacji organów umiejscowionych w treści rozdziału IX Konstytucji RP (Organy kontroli państwowej i ochrony prawa). W praktyce jednak i późniejsze orzecznictwo organów władzy sądowniczej oraz stanowisko doktryny identyfikowały pojęcie „,nadzoru” z konstytucyjną zasadą ochrony pracy, a konkretnie z wywiązaniem z ciążącego na państwie obowiązku „ochrony pracowników jako »słabszej« strony stosunku pracy"l1. Podnoszono przy tym, że istota działań państwa w tym zakresie powinna polegać ,na ustanowieniu mechanizmów służących przeciwdziałaniu niezgodnym z prawem lub zasadami współżycia społecznego działaniom pracodawców"12 , co powinno się wiązać nie tylko z „,wyposażeniem” konkretnej instytucji w kompetencje kontrolne, ale szersze, umożliwiające organowi podejmowanie - odpowiednich do potrzeb — działań władczych, co do

10 W orzeczeniu z 9 listopada 1999 roku, K 28/98, TK stwierdził, że konieczna szczegółowość („głębokość”) regulacji ustawowej „,zależy od normowanej materii — w niektórych dziedzinach (na przykład prawo karne, czy mówiąc szerzej — regulacje represyjne) zarysowuje się bezwzględna wyłączność ustawy, nakazująca normowanie w samej ustawie właściwie wszystkich elementów definiujących stronę podmiotową czy przedmiotową czynów karalnych". Ta sama zasada dotyczy kwestii wskazanych w art. 65 ust. 1, 66 ust. 1 i 2 Konstytucji RP.

11 Wyrok TK z 26 kwietnia 2018 roku, K 6/15 z powołaniem się na wcześniejsze orzeczenia z: 4 października 2005 roku, K 36/03; 18 października 2005 roku, SK 48/03; 24 października 2006 roku, SK 41/05.

12 Ibidem, z odwołaniem się do stanowiska L. Garlickiego, Uwagi do art. 24, [w:] Konstytucja Rzeczypospolitej Polskiej. Komentarz, t. 5, red. L. Garlicki, Warszawa 2003, s. 2-3. 
zasady nakierowanych na ochronę konstytucyjnych wolności i praw podmiotów słabszych ${ }^{13}$.

Biorąc powyższe pod uwagę, można też domniemywać, że ze względu na zakres i charakter działań nadzorczych nad warunkami wykonywania pracy przyjmowano koncepcję szerokiego spektrum organów i instytucji, które w ramach przyznanych kompetencji uprawnione byłyby do ich podejmowania. Konstytucyjna konkretyzacja tylko jednego z nich przy jednoczesnym pominięciu pozostałych (na przykład sądów) prowadziłaby do powstania niepotrzebnej hierarchizacji systemu instytucjonalnego.

Niezależnie od tych domniemań należy wskazać na konstytucyjną zasadę rzetelności i sprawności jako wyznacznik znaczenia i roli każdej instytucji publicznej w Polsce. Poszanowanie zasady rzetelności i sprawności w kontekście funkcjonowania całego państwa wymaga, aby ustawodawca wziął pod uwagę co najmniej dwa fundamentalne założenia, to jest tego, że stanowione przez niego regulacje muszą służyć:

— zapewnieniu należytej ochrony konstytucyjnie gwarantowanych wolności i praw jednostki;

- stworzeniu funkcjonalnego i efektywnie działającego aparatu publicznoprawnego, którego organy i instytucje wyposażone są w instrumenty umożliwiające jak najpełniejszą, a co za tym idzie - jak najsprawniejszą i efektywną realizację nałożonych na nie zadań.

Nie budzi wątpliwości, że zapewnienie rzetelności i sprawności działania instytucji publicznych, szczególnie tych, które zostały stworzone w celu realizacji i ochrony gwarantowanych przez Konstytucję RP wolności i praw jednostki, należy do ,wartości mających rangę konstytucyjną”. Jak wielokrotnie podkreślał Trybu-

13 Tak definiował pracowników TK, zob. na przykład wyrok z dnia 22 maja 2013 roku, P 46/11. Co istotne przecież, pracodawcy, i to nie tylko osoby fizyczne prowadzące działalność gospodarczą, są również beneficjentami konstytucyjnych wolności i praw jednostki. Oczywiście, bezpośrednim adresatem praw i wolności jest człowiek (osoba fizyczna), to nic nie stoi na przeszkodzie, by na istniejące prawa i wolności powoływały się także inne podmioty prawa prywatnego, bądź to bezpośrednio, bądź ze względu na charakter przyznanych uprawnień. Horyzontalne obowiązywanie wolności i praw jednostki jest równoznaczne z dopuszczeniem możliwości powoływania się przez osoby fizyczne, a także osoby prawne na gwarantowane konstytucyjnie uprawnienia w zakresie rozstrzygania sporów cywilnoprawnych i pracowniczych, do jakich może między nimi dochodzić. W takim ujęciu normy konstytucji mogłyby się stać podstawą rozstrzygania tych sporów, nawet z pominięciem istniejących w tym zakresie norm ustawowych. Na temat horyzontalnego obowiązywania zob. szerzej opracowania zawarte w monografii zbiorowej Horyzontalne oddziaływanie Konstytucji Rzeczypospolitej Polskiej oraz Konwencji o Ochronie Praw Człowieka i Podstawowych Wolności, (,Studia i Materiały Trybunału Konstytucyjnego” 56), red. A. Młynarska-Sobaczewska, P. Radziewicz, Warszawa 2015, s. 5 (wprowadzenie) n., zwłaszcza zaś artykuł S. Jarosz-Żukowskiej, Horyzontalne działanie praw człowieka w sferze stosunków pracowniczych w świetle Konstytucji RP, s. 137 n. 
nał Konstytucyjny ${ }^{14}$, „wynika to jasno z tekstu wstępu do Konstytucji (tzw. preambuły), w którym jako dwa główne cele ustanowienia Konstytucji wymieniono: zagwarantowanie praw obywatelskich oraz zapewnienie rzetelności i sprawności działania instytucji publicznych"15.

\section{ISTOTA SYSTEMOWYCH GWARANCJI ORGANU POWOŁANEGO DO SPRAWOWANIA NADZORU NAD WARUNKAMI WYKONYWANIA PRACY}

Nie budzi wątpliwości, że obowiązująca Konstytucja RP w czytelny sposób definiuje zakres działań organu (organów, struktur), którego celem ma być sprawowanie w imieniu państwa polskiego nadzoru nad warunkami wykonywania pracy ${ }^{16}$. Istotna część wskazanych przepisów Ustawy Zasadniczej może być stosowana bezpośrednio, a w konsekwencji stanowić wystarczającą podstawę działania organu państwowego w zakresie ochrony konstytucyjnych wolności i praw pracowniczych ${ }^{17}$. W konsekwencji rzetelność i sprawność działania ustawowo ukształtowanego organu sprawującego nadzór i kontrolę przestrzegania prawa pracy, w tym przepisów oraz zasad bezpieczeństwa i higieny pracy, jakim jest niewątpliwie Państwowa Inspekcja Pracy ${ }^{18}$, oznacza, że reprezentujący go funkcjonariusze (organy) ${ }^{19}$ działają:

14 Zob. wyroki TK: z dnia 7 stycznia 2004 roku, K 14/03; z dnia 18 lutego 2004 roku, K 12/03; z dnia 7 listopada 2005 roku, P 20/04; z dnia 22 września 2006 roku, U 4/06; z dnia 15 stycznia 2009 roku, K 45/07; z dnia 12 marca 2007 roku, K 54/05.

15 Wyrok TK z dnia 16 grudnia 2009 roku, Kp 5/08.

16 Oczywiście należy pamiętać, że nadzór i kontrolę przestrzegania zasad oraz przepisów higieny pracy i warunków środowiska pracy sprawuje Państwowa Inspekcja Sanitarna, działająca na podstawie ustawy z dnia 14 marca 1985 roku o Państwowej Inspekcji Sanitarnej, tekst jedn. Dz.U. z 2019 r. poz. 59.

${ }^{17} \mathrm{Na}$ temat bezpośredniego stosowania zob. R. Balicki, Bezpośrednie stosowanie Konstytucji, „Krajowa Rada Sądownictwa” 2016, nr 4, s. 13-19; zob. też postanowienie SN z 26 marca 2019 roku, III UK 239/18 i przywołaną tam literaturę. Bezpośrednie stosowanie wymaga oczywiście analizy treści art. 81 Konstytucji RP.

18 Ustawa z 13 kwietnia 2007 roku o Państwowej Inspekcji Pracy, tekst jedn. Dz.U. z 2018 r. poz. $623 \mathrm{ze}$ zm.

19 Specyfika struktury organizacyjnej PIP prowadziła do istotnych wątpliwości w zakresie na przykład udostępniania informacji publicznej. Za wadliwe sąd uznał wydanie decyzji o odmowie udostępnienia informacji publicznej przez Inspektor Pracy Okręgowego Inspektoratu Pracy w Gdańsku, będącego organem niższego stopnia w stosunku do adresata wniosku, to jest Okręgowego Inspektora Pracy w Gdańsku, por. wyrok NSA z dnia 16 grudnia 2009 roku, I OSK 1116/09; zob. też wyrok NSA z dnia 27 lipca 2012 roku, I OSK 772/12. 
— na podstawie i w granicach prawa powszechnie obowiązującego (zasada legalizmu — art. 7 Konstytucji) ${ }^{20}$;

— w interesie publicznym wyrażającym się w zapewnieniu skutecznej ochrony wolności i praw zagwarantowanych w Konstytucji RP oraz innych skonkretyzowanych w przepisach ustawowych, zachowując przy tym zawodową bezstronność;

— w taki sposób, aby podejmując wszystkie przewidziane prawem czynności, eliminować możliwość przedłużania się postępowania.

Nie budzi przy tym wątpliwości, że sprecyzowane przez ustawodawcę środki prawne zapewniające sprawne działanie Państwowej Inspekcji Pracy nie mogą przybrać postaci pozornej. Jednocześnie ich zakres i charakter nie mogą prowadzić do tego, że wykonywanie funkcji organu nadzorczego będzie nieefektywne lub/i nieskuteczne. Ustawodawca, konkretyzując model funkcjonowania organu (lub systemu organów), musi więc wziąć pod uwagę to, że ze względu na istotę kompetencji — w tym wypadku Państwowej Inspekcji Pracy — działalność reprezentujących go funkcjonariuszy musi wiązać się z władczym wkroczeniem w sferę wolności i praw podmiotu, wobec którego prowadzone są konkretne czynności 21 . Oczywiste bowiem staje się to - szczególnie z punktu widzenia przedsiębiorców będących pracodawcami — że będziemy mieli do czynienia z kolizją wolności i praw konstytucyjnych. Tacy przedsiębiorcy są również podmiotami, które skutecznie mogą się powoływać na ochronę konstytucyjnych wolności i praw. Często przywoływana jest przez nich ochrona nie tylko gwarantowanej konstytucyjnie wolności prowadzenia działalności gospodarczej (art. 20 i 22), lecz także tajemnicy korespondencji (art. 49), własności (art. 21 i 64) itp. Z punktu widzenia przyjętych w Konstytucji RP regulacji i znaczenia pracy (oraz jej ochrony) rozstrzygnięcie takich kolizji wymaga każdorazowo przeprowadzenia testu ważenia interesów (tak zwany test szkody). Przeprowadzenie takiego testu jest obowiązkiem każdego organu rozstrzygającego, także z punktu widzenia wyeliminowania zarzutu arbitralności w zakresie stosowania prawa ${ }^{22}$.

20 Zob. więcej Proces prawotwórczy w świetle orzecznictwa Trybunału Konstytucyjnego. Wypowiedzi Trybunatu Konstytucyjnego dotyczace zagadnień zwiąanych z procesem legislacyjnym, Warszawa 2015, s. 24, 215 n.

${ }^{21}$ Zgodzić się trzeba z tym, że działania te (wystąpienia) mogą być traktowane różnie. W pewnych przypadkach będą to działania z szeroko rozumianej sprawy administracyjnej, z drugiej niemające charakteru aktu władczego, a ograniczające się wyłącznie do stwierdzenia faktu naruszenia przepisów prawa pracy i wezwania do jego usunięcia w wyznaczonym terminie, zob. więcej wyrok NSA z dnia 18 lutego 2009 roku, I OSK 405/08; wyrok WSA z dnia 28 lutego 2014 roku, II SA/Po 975/13 i cytowane tam orzecznictwo.

22 Istotne w tym zakresie staje się podniesienie, że organy stosujące prawo nie mogą decydować (definiować) ostatecznie o treści i charakterze ostatecznie obowiązujących uregulowań. Czynić to może jedynie ustawodawca, choć pytaniem podstawowym pozostaje to, czy zawsze się z tego obowiązku należycie wywiązuje. 


\section{PAŃSTWOWA INSPEKCJA PRACY JAKO ORGAN WŁADZY PUBLICZNEJ - CHARAKTERYSTYKA SYSTEMOWA}

Rola państwa sprowadza się nie tylko do powstrzymania się od arbitralnych działań stanowiących ingerencję w sferę praw i wolności jednostki, lecz także zabezpieczenia jej uprawnień, $\mathrm{w}$ tym przed naruszeniami ze strony innych jednostek oraz podmiotów (też szeroko rozumianych pracodawców). Wymaga to podjęcia przez właściwe władze odpowiednich działań prawodawczych, mających na celu stworzenie pożądanych warunków do realizacji wszystkich gwarantowanych konstytucyjnie i ustawowo wolności i praw jednostki. Wynikiem działań ustawodawcy w sferze gwarancji i ochrony wolności oraz praw musi być stworzenie, po pierwsze, systemu organów oraz instytucji, których celem jest zapobieganie naruszeniom, po drugie zaś takich procedur, które umożliwią jednostce wyeliminowanie zagrożeń mogących mieć miejsce lub skutków działań (zaniechań), które już zaistniały.

Obecnie dominuje szeroka koncepcja definiowania władzy publicznej. Mając na względzie europejską koncepcję (system Rady Europy i unijny), przyjmuje się, że jest to „wszelka jednostka organizacyjna prawa publicznego każdego szczebla oraz wszelka osoba prywatna, jeśli wykonuje uprawnienia władzy publicznej”23.

Trybunał Konstytucyjny, wypowiadając się na temat władzy publicznej, wskazywał, że pojęcie to

obejmuje wszystkie władze konstytucyjne państwa lub samorządu, a także inne instytucje, o ile wykonują funkcje ,władzy publicznej” w wyniku powierzenia czy przekazania im tych funkcji. Wykonywanie władzy publicznej dotyczy wszelkich form działalności państwa, samorządu terytorialnego i innych instytucji publicznych, które obejmują bardzo zróżnicowane formy aktywności. Wykonywanie takich funkcji łączy się z reguły, chociaż nie zawsze, z możliwością władczego kształtowania sytuacji jednostki. Dotyczy to obszaru, na którym może dojść do naruszenia praw i wolności jednostki ze strony władzy publicznej ${ }^{24}$.

Jednocześnie trzeba jednak wskazać, że klasyczne pojęcie organu władzy nie może być identyfikowane z pojęciem władzy publicznej. Trybunał podkreślał, że

W pojęciu władzy publicznej mieszczą się bowiem także inne instytucje niż państwowe i samorządowe, o ile wykonują funkcje władzy publicznej w wyniku powierzenia czy przekazania im tych funkcji przez organ władzy państwowej lub samorządowej. Wykonywanie władzy publicznej dotyczy wszelkich form działalności państwa, samorządu terytorialnego i innych instytucji publicznych, które obejmują bardzo zróżnicowane formy działalności ${ }^{25}$.

23 Z. Witkowski, A. Bień-Kacała, O potrzebie redefinicji terminu ,organ państwa”, [w:] W stużbie dobru wspólnemu. Księga Jubileuszowa dedykowana Profesorowi Januszowi Trzcińskiemu, red. R. Balicki, M. Masternak-Kubiak, Warszawa 2012, s. 409, z powołaniem się na opracowanie E. Bagińskiej, Odpowiedzialność odszkodowawcza za wykonywanie władzy publicznej, Warszawa 2006, s. 236-241.

$24 \mathrm{Z}$ uzasadnienia wyroku TK z dnia 20 stycznia 2004 roku, SK 26/03.

25 Z uzasadnienia wyroku TK z dnia 20 stycznia 2004 roku, SK 26/03; por. też uchwała TK z dnia 14 maja 1997 roku, W 7/96. 
Oczywiście trudno dokonać jednoznacznego umiejscowienia inspekcji pracy w kontekście zasady podziału władz (art. 10 Konstytucji RP). Biorąc pod uwagę treść Konstytucji RP oraz orzecznictwo Trybunału Konstytucyjnego, mamy pewność, że ani sama Państwowa Inspekcja Pracy, ani jej organy nie są traktowane jako organy władzy sądowniczej, ani tym bardziej organy sprawujące wymiar sprawiedliwości ${ }^{26}$. Jednocześnie jednak należy wykluczyć możliwość przyporządkowania inspekcji — co oczywiste — do władzy ustawodawczej, którą sprawuje Sejm i Senat.

Państwową Inspekcję Pracy niekiedy próbuje się uznać za quasi-sądowy organ rozstrzygający. Wydaje się jednak, że nawet przy uwzględnieniu niektórych kompetencji szczególnych wskazanych w art. 11 ustawy (art. 11 pkt 7 nakaz płatniczy oraz uprawnienie do nakładania grzywny w drodze mandatu karnego) nie można odpowiednio uzasadnić, że mamy do czynienia z faktycznym orzekaniem przez organ w sprawie sądowej ${ }^{27}$. Przychylając się ku temu stanowisku, należy również zaprzeczyć możliwości identyfikowania działalności rozstrzygającej Państwowej Inspekcji Pracy z funkcjonowaniem organu (organów) orzeczniczych identyfikowanych z sądem unijnym ${ }^{28}$.

Nie budzi przy tym wątpliwości, że istotna część działań podejmowanych przez organy Państwowej Inspekcji Pracy ma charakter władczy, który identyfikowany jest z klasycznymi rozstrzygnięciami z zakresu administracji ${ }^{29}$, dodatkowo wzmoc-

26 Zgodnie z treścią Konstytucji RP władzę sądowniczą sprawują sądy i Trybunały. Zgodnie zaś z treścią art. 175 Konstytucji RP wymiar sprawiedliwości sprawują: Sąd Najwyższy, sądy powszechne, sądy administracyjne oraz sądy wojskowe. Sąd wyjątkowy może być natomiast ustanowiony tylko na czas wojny. Na temat pojęć: władza sądownicza, wymiar sprawiedliwości zob. B. Banaszak, Konstytucja Rzeczypospolitej Polskiej. Komentarz, Warszawa 2009, s. 87-88.

27 D. Makowski, Pozycja prawna Państwowej Inspekcji Pracy, „Państwo i Prawo”2010, nr 3 , s. 45 .

28 TS UE w sprawie Forposta S.A., ABC Direct Contact sp. z o.o. przeciwko Poczcie Polskiej S.A. z 13 grudnia 2012 roku (C-465/11), stwierdził że można za taki uznać organ, który jest ,stałym organem powołanym na mocy ustawy, wyposażonym w szerokie kompetencje orzecznicze, rozpoznając odwołania od niezgodnych z przepisami ustawy czynności zamawiających podejmowanych $\mathrm{w}$ toku postępowania o udzielenie zamówienia publicznego stosuje przepisy prawne, i wreszcie jej członkowie w trakcie orzekania są niezawiśli i podlegają jedynie ustawom. Gwarancję niezawisłości stanowią określone w ustawie zakazy: podejmowania dodatkowego zatrudnienia i innych zajęć zarobkowych (z wyjątkami określonymi w ustawie), a także prowadzenia działalności gospodarczej w formach określonych w ustawie”. Z tego punktu widzenia Państwowa Inspekcja Pracy nie może być za taki organ uznana.

${ }_{29}$ Zob. więcej wyrok NSA z dnia 18 lutego 2009 roku, I OSK 405/08; wyrok WSA z dnia 28 lutego 2014 roku, II SA/Po 975/13 i cytowane tam orzecznictwo. Podkreślano już kilkanaście lat temu, że „Organy PIP stosują środki prawne o charakterze stanowiącym, władczym, zwane nakazami, które są decyzjami administracyjnymi oraz środki pokontrolne niewładcze będące wyrazem funkcji kontrolnej PIP. W katalogu środków PIP nakazy inspektorów pracy mają dużą siłę oddziaływania, są instrumentem przymusowego kształtowania prawidłowego układu stosunków pomiędzy pracownikiem a podmiotem kontrolowanym, w związku z tym nakaz inspektora pracy zajmuje centralne miejsce w systemie środków nadzorczych PIP” — T. Niedziński, Opinia prawna 
nionymi uznaniem organów Państwowej Inspekcji Pracy za organy egzekucyjne ${ }^{30}$. Jednocześnie część zadań realizowana jest w formie pozawładczej, przyjmującej różnorodną postać (na przykład edukacyjną, profilaktyczną, naukową itp.).

Zasadniczo powinniśmy więc uznać, że Państwową Inspekcję Pracy należy umiejscowić w ramach organizacyjnych władzy wykonawczej ${ }^{31}$. Mając jednak na względzie, że wiele różnych organów państwowych w Polsce funkcjonuje poza klasyczną zasadą podziału władz, możemy również przyjąć, że specyfika leżąca u podstaw wyodrębnienia tej instytucji będzie determinowała odrębną jego klasyfikację, to jest jako szczególnego rodzaju organu, którego funkcjonariusze, działając w ramach służby publicznej ${ }^{32}$, wykonują swe obowiązki na podstawie i w granicach prawa powszechnie obowiązującego (art. 7 Konstytucji RP) ${ }^{33}$, w zakresie działań umiejscowionych poza klasycznym elementem trójpodziału władz, to jest w obszarze nadzoru, kontroli i respektowania prawa (w tym kontroli legalności zatrudniania), ze szczególnym uwzględnieniem ochrony wolności i praw jednostki (pracownika) w związku ze świadczeniem (wykonywaniem) pracy na rzecz konkretnego (konkretnych) pracodawców.

na temat: Prawno-ustrojowy status Państwowej Inspekcji Pracy a skuteczność jej działania w świetle obecnych rozwiazań krajowych i europejskich, Kancelaria Senatu Biuro Informacji i Dokumentacji, Dział Analiz i Opracowań Tematycznych, Opinie i Ekspertyzy OE-84, październik 2008, s. 11.

30 Jak wskazuje się: „Organem egzekucyjnym Państwowej Inspekcji Pracy jest inspektor pracy bądź okręgowy inspektor pracy, który wydał decyzję w I instancji (art. $20 \S 2$ - postępowanie egzekucyjne w administracji). W celu przymusowego wykonania obowiązków wynikających z decyzji organów PIP najczęściej stosowany jest środek egzekucji w postaci grzywny, która może być nakładana kilkakrotnie w tej samej lub wyższej kwocie (art. 121 — postępowanie egzekucyjne w administracji)" — T. Niedziński, op. cit., s. 13.

31 Byłoby to zgodne z tym, co podkreślano w uzasadnieniu do projektu ustawy uchwalonej w 2007 roku. Również w opracowaniach podkreślano, że: „W nowej ustawie PIP zyskała status organu administracyjnego z tym, że różni się on od klasycznego ujęcia organu w prawie i doktrynie [...] W art. 1 ustawy Państwowa Inspekcja Pracy oznaczona jest jako „organ” i jednocześnie nazwana jest ,inspekcją” w całości in stricto. W swej nazwie PIP, z punktu widzenia nauki administracji, zawiera właściwie wszystkie elementy charakterystyczne dla tzw. inspekcji specjalnej, konieczne do wykonywania państwowej kontroli w określonym ustawą zakresie wraz z możliwością wiążącego wpływania na jednostki kontrolowane (J. Jagielski, Kontrola administracji publicznej, Warszawa 2007, s. 192 n.). W systemie aparatu państwowego inspekcja pracy, jako instytucja kontrolna, jest inspekcją wielofunkcyjną, gdyż nie ogranicza się do zadań i kompetencji tylko z zakresu kontroli. Funkcje PIP obejmują także inne zadania na przykład opiniodawcze, informacyjne, szkoleniowe a nadto - czynności o charakterze prawno-technicznym (rejestracja układów zbiorowych pracy, zbieranie danych o sporach zbiorowych i przystąpienia stron do negocjacji). W efekcie Państwowa Inspekcja Pracy jest instytucją realizującą funkcje administracji publicznej (J. Lang, Rozważania nad prawnym położeniem Państwowej Inspekcji Pracy, Wrocław 1999, s. 212; W. Muszalski, Państwowa Inspekcja Pracy, „Przegląd Ustawodawstwa Gospodarczego” 1981, nr 10-12, s. 222)”T. Niedziński, op. cit., s. 3-4.

${ }^{32}$ Zob. więcej A. Łukaszczuk, Prawo dostępu do stużby publicznej, [w:] Realizacja i ochrona..., s. 351-361; zob. też wyrok TK z dnia 14 grudnia 2010 roku, K 20/08.

33 Zob. więcej K. Kiczka, Krajowy organ administracji publicznej w prawie unijnym, Wroclaw 2013, s. 202-205. 
Jak wskazuje się w literaturze przedmiotu, pojęcie ochrony prawnej w wąskim znaczeniu identyfikuje się z działalnością wyspecjalizowanych organów państwowych, podejmowaną w celu ochrony prawa ${ }^{34}$, w szerszym zaś jako „strzeżenie nienaruszalności norm prawnych będących regułami obowiązującego zachowania w państwie"35.

Zakres i charakter zadań (kompetencji) i obowiązków Państwowej Inspekcji Pracy różni się wprawdzie od konstytucyjnych organów ochrony i kontroli prawa (do takich zalicza się Najwyższą Izbę Kontroli i Rzecznika Praw Obywatelskich ${ }^{36}$, także Rzecznika Prawa Dziecka). W pewnym jednak zakresie różnica ta — w odniesieniu do specyfiki działania Krajowej Rady Radiofonii i Telewizji ${ }^{37}$ — nie jest już tak widoczna, podobnie jak w wypadku Prezesa Urzędu Ochrony Danych Osobowych ${ }^{38}$ i wielu innych organów ${ }^{39}$, które ukształtowane zostały na poziomie regulacji ustawowej.

Pomimo więc bardzo złożonego zakresu zadań i obowiązków, a przede wszystkim środków prawnych, które w swojej działalności wykorzystywać może Państwowa Inspekcja Pracy, nie będzie błędem zaliczenie jej do organów ochrony i kontroli prawa ${ }^{40}$. Mając na względzie cel jej działalności, w szczególności przez

34 S. Serafin, B. Szmulik, Organy ochrony prawnej RP, Warszawa 2007, s. 1.

35 Ibidem.

36 Zob. więcej M. Rojewski, Organy ochrony prawnej. Orzecznictwo, Warszawa 2011, s. 239 n.

37 J. Rzucidło, Krajowa Rada Radiofonii i Telewizji jako konstytucyjny organ ochrony wolności stowa i prawa do informacji w radiofonii i telewizji, [w:] Realizacja i ochrona..., s. $886 \mathrm{n}$.

38 Ustawa z dnia 10 maja 2018 roku o ochronie danych osobowych, Dz.U. z 2018 r. poz. 1000, art. $34 \mathrm{n}$.

39 Zob. więcej T. Demenecki, J. Bodio, G. Borkowski, Ustrój organów ochrony prawnej. Część szczegółowa, Warszawa 2015.

40 W zasadzie tak właśnie definiuje się rolę i znaczenie Państwowej Inspekcji Pracy w orzecznictwie sądów administracyjnych. Jak wskazuje Naczelny Sąd Administracyjny: „Należy podkreślić, że zgodnie z art. 1 ustawy o Państwowej Inspekcji Pracy Państwowa Inspekcja Pracy jest organem powołanym do sprawowania nadzoru i kontroli przestrzegania prawa pracy, w szczególności przepisów i zasad bezpieczeństwa i higieny pracy, a także przepisów dotyczących legalności zatrudnienia i innej pracy zarobkowej w zakresie określonym w ustawie. Status prawnoustrojowy Państwowej Inspekcji Pracy opiera się na państwowym charakterze tej instytucji, która podlega bezpośrednio Sejmowi (art. 2 ustawy). Wykonywanie zadań przez Państwową Inspekcję Pracy cechuje wyposażenie tej instytucji w szerokie kompetencje obejmujące nie tylko upoważnienie do prowadzenia kontroli przestrzegania przez pracodawców przepisów prawa pracy, ale także do stosowania środków nadzorczych, których wykonanie obwarowane jest przymusem państwowym. Na podkreślenie zasługuje także powszechny charakter uprawnień organów inspekcji pracy; zgodnie bowiem z art. 13 ustawy nadzorem i kontrolą obejmuje wszystkie podmioty, na rzecz których wykonywana jest praca, niezależnie od tego, czy są pracodawcami, czy nie (zob. A. Jasińska-Cichoń, Komentarz do ustawy o Państwowej Inspekcji Pracy, 2008). Taka pozycja Państwowej Inspekcji Pracy w systemie organów kontroli w państwie wynika z konstytucyjnych zasad ustrojowych; przede wszystkim z art. 24 Konstytucji RP, zgodnie z którym praca znajduje się pod ochroną Rzeczypospolitej Polskiej i który na państwo nakłada obowiązek sprawowania nadzoru nad warunkami wykonywania pracy, jak również z gwarantowanego Konstytucją prawa każdego do bezpiecznych i higienicznych warunków pracy (art. 66). Należy ponadto podkreślić, że powołanie inspekcji pracy, a także zadania oraz uprawnienia przysługujące jej organom wynikają z Konwencji nr 81 Między- 
pryzmat ochrony konstytucyjnych wolności i praw jednostki, taki pogląd wydaje się uzasadniony. Jak wskazuje się w literaturze przedmiotu, analiza obowiązujących regulacji ustawowych pozwala stwierdzić, że Państwowa Inspekcja Pracy realizuje zadania w szerokim ,obszarze kontroli i nadzoru przestrzegania prawa, a także w sferze udzielania pomocy prawnej", a to oznacza, że działania takie należy uznać za wchodzące w zakres pojęcia „ochrona prawna”. W konsekwencji przyjmuje się, że zastosowanie kryterium funkcji organu prowadzi do wniosku, że jest to organ ochrony prawa sensu largo, a więc taki, którego celem jest ochrona „praw obywatelskich oraz interesów indywidualnych"41.

Tego rodzaju konstatacja oznacza w konsekwencji konieczność przyjęcia odpowiednich rozwiązań systemowych (co najmniej na poziomie rozwiązań ustawowych), których celem będzie zagwarantowanie Państwowej Inspekcji Pracy niezależności ${ }^{42}$ oraz neutralności ${ }^{43}$ na co najmniej kilku płaszczyznach:

— instytucjonalnej, charakteryzującej się brakiem politycznego wpływu na charakter i zakres podejmowanych przez Państwową Inspekcję Pracy działań, a w szczególności na rozstrzygnięcia podejmowane przez jej funkcjonariuszy (organy). Wiąże się równocześnie z zagwarantowaniem niezależności działania, opierając się na zasadzie zaufania do organu nie tylko stron konkretnego postępowania, lecz także zaufania społecznego do publicznego, zawodowego, profesjonalnego charakteru instytucji i repezentujących ją funkcjonariuszy (organów) ${ }^{44}$;

— osobistej, oznaczającej konieczność wyraźnego skonkretyzowania przesłanek odwołania ze stanowiska. Przesłanki takie muszą mieć charakter obiektywny i wiązać się z naruszeniem zasady legalizmu oraz norm etycznych istotnych z punktu widzenia wykonywanej funkcji;

— funkcjonalnej, zapewniającej nieskrępowany faktycznie, a jedynie sprecyzowany prawnie przepisami prawa powszechnie obowiązującego zakres i charakter działań podejmowanych przez Państwową Inspekcję Pracy w każdym przypadku zagrożenia i/lub naruszenia praw pracowniczych;

narodowej Organizacji Pracy (MOP) w sprawie inspekcji pracy w przemyśle i handlu, którą Polska ratyfikowała w dniu 19 kwietnia 1995 roku. Zgodnie zaś z art. 87 ust. 1 Konstytucji ratyfikowana umowa międzynarodowa stanowi źródło powszechnie obowiązującego prawa w Rzeczypospolitej Polskiej” — wyrok NSA z dnia 8 lipca 2011 roku, I OSK 289/11.

${ }^{41}$ D. Makowski, op. cit., s. 44 i 46.

42 Jak podkreśla się w opracowaniach dotyczących Państwowej Inspekcji Pracy: „Niezależność, niezawisłość to podstawowe standardy ustroju inspekcji pracy — organów ochrony prawnej” — T. Niedziński, op. cit., s. 10. Trudno jednak wskazać sensu stricto prawne gwarancje owej „niezawisłości”.

43 Wymóg neutralności wynika z postanowień Konwencji nr 81 MOP, dotyczącej inspekcji pracy w przemyśle i handlu, pozostawiającej poszczególnym państwom swobodę w tworzeniu inspekcji pod warunkiem zachowania neutralności inspekcji w relacjach kontrolnych.

${ }_{44}$ Zob. więcej H. Izdebski, Zarządzanie etyka za pośrednictwem kodeksów etyki zawodowej, [w:] Etyka w stużbie publicznej, red. J. Czaputowicz, Warszawa 2012, s. 47. 
— operacyjnej, która wiąże się z koniecznością zapewnienia i zabezpieczenia przez organy władzy ustawodawczej, wykonawczej środków prawnych oraz gwarancji niezbędnych do realizacji określonych przez prawo powszechnie obowiązujących zadań i obowiązków ciążących na funkcjonariuszach reprezentujących Państwową Inspekcję Pracy;

— organizacyjnej i finansowej, stwarzającej odpowiednie warunki w zakresie dynamicznego dostosowywania struktury organizacyjnej służby do potrzeb i zmieniającego się otoczenia rynku pracy, a w konsekwencji sprawnego wykonywania nałożonych zadań i obowiązków. Konieczne jest więc pozostawienie przez ustawodawcę niezbędnej autonomii w zakresie definiowania konkretnych rozwiązań organizacyjnych, których efektem staje się zwiększenie rzetelności, efektywności i skuteczności ${ }^{45}$ działań organu;

— prawnej, która powinna charakteryzować się przyznaniem Państwowej Inspekcji Pracy odrębnej osobowości prawnej, uwzględniającej specyfikę jej działania, i zmierzać do jak najszerszego interweniowania w sytuacji stwierdzenia naruszeń prawa powszechnie obowiązującego.

Obowiązek działania organów państwowych na podstawie i w granicach prawa dotyczy więc nie tylko ,procesu stanowienia prawa na każdym hierarchicznym poziomie źródeł prawa, stosowania prawa (przez organy wykonawcze, ale i władzy sądowniczej, a także spoza trójpodziału), jak również egzekwowania prawa [...]"46. Trybunał Konstytucyjny wielokrotnie podkreślał, że

wymóg podstawy prawnej dla działania organów władzy publicznej oznacza, iż organy te mogą działać wyłącznie na podstawie upoważnień przewidzianych w prawie. Brak regulacji prawnej upoważniającej do podjęcia danego działania należy uznać za równoznaczny z zakazem tego działania. Wymóg podejmowania działań na podstawie prawa ściśle związany jest $\mathrm{z}$ wymogiem podejmowania działań w granicach prawa. Prawo udzielając organom władzy publicznej upoważnień do podejmowania określonych działań, wyznacza jednocześnie granice tych działań. Wykroczenie poza te granice, jak podkreśla się w nauce prawa konstytucyjnego, kwalifikować należy jako działanie bez podstawy prawnej, zaś działanie bez podstawy prawnej to równocześnie działanie wykraczające poza granice wyznaczone przez prawo ${ }^{47}$.

45 Trybunał Konstytucyjny w wyroku z dnia 27 listopada 2007 roku, SK 39/06, stwierdził że ,preambuła jest częścią tekstu Konstytucji, a jej wypowiedzi mogą mieć, na tle określonej sprawy, zwłaszcza w związku z konkretnymi przepisami Konstytucji, walor normatywny". Co tutaj istotniejsze, w wyroku z dnia 12 marca 2007 roku, K 54/05, Trybunał poszedł jeszcze dalej i uczynił preambułę już wyraźnie wzorcem kontroli, a ściślej wyrażoną w niej zasadę współdziałania, pomocniczości oraz skuteczności i rzetelności działania instytucji publicznych. Wprost w sentencji wyroku, a nie w uzasadnieniu Trybunał stwierdził, że ,art. 87 ust. 3 ustawy z dnia 27 marca 2003 r. o planowaniu i zagospodarowaniu przestrzennym [...] jest zgodny: a) z preambułą Konstytucji Rzeczypospolitej Polskiej w zakresie, w jakim wyraża ona zasadę współdziałania władz, zasadę pomocniczości oraz wymóg skuteczności i rzetelności działania instytucji publicznych".

46 W. Sokolewicz, Komentarz do art. 7 Konstytucji RP, [w:] Konstytucja Rzeczypospolitej Polskiej. Komentarz, t. 2, red. L. Garlicki, Warszawa 2003, s. 11.

$47 \mathrm{Z}$ uzasadnienia wyroku TK z dnia 14 czerwca 2000 roku, P 3/00. 
Działanie na podstawie prawa warunkuje bowiem

możność podejmowania tylko takich rozstrzygnięć i działań władczych, które są [...] przez prawo wyraźnie dozwolone lub nakazane, wszystko inne jest bowiem bezwzględnie zakazane. Natomiast z nakazu działania w granicach prawa wynika obowiązek przestrzegania prawa do czasu legalnej jego zmiany ${ }^{48}$.

Istotne jest również przypomnienie, że obok zasady legalizmu i wynikającego z niej zakazu podejmowania decyzji (działań) bez podstawy prawnej wynika również zakaz unikania przez organ władzy publicznej podejmowania decyzji, „jeżeli wiążące normy prawne nakładają na niego taki obowiązek" ${ }^{\prime 49}$, co biorąc pod uwagę powyższe, oznacza, że ma obowiązek podjęcia działania na podstawie i w ramach istniejących (przewidzianych prawem) kompetencji.

Ważne w tym miejscu staje się jednak podkreślenie, że o ile zakres potencjalnych działań państwa, a w szczególności organów władzy ustawodawczej i wykonawczej, może być oparty na różnych kryteriach (także politycznych), to kryterium takiego nie powinno się odnosić do funkcjonowania wyspecjalizowanego organu ochrony prawnej, którego podstawowym zadaniem staje się ochrona pracy ${ }^{50}$, a więc przeciwdziałanie praktykom będącym naruszeniami prawa, zasad etycznych czy wreszcie zasad współżycia społecznego. Polityczne uwarunkowania (względy) nie mogą być bowiem podstawą (przesłanką) ingerowania w kształt stosunków pracy między pracownikami a pracodawcą, a w szerszym znaczeniu — ochroną konstytucyjnych wolności i praw jednostki w tym obszarze.

\section{POSTULATY DE LEGE LATA I DE LEGE FERENDA}

Jeżeli spojrzymy na ustawowo sprecyzowany zakres działania Państwowej Inspekcji Pracy, to zauważymy, że polski ustawodawca miał i w dalszym ciągu ma istotne problemy w należytym zdefiniowaniu pozycji Inspekcji i reprezentujących ją organów (inspektorów).

Argumentów uzasadniających takie twierdzenie jest co najmniej kilka.

Po pierwsze, wątpliwości budzi brak ustawowo zdefiniowanej kadencji Głównego Inspektora Pracy. Regulacja przyjęta w art. 4 ustawy nie może być uznana za wzorzec modelu gwarantującego samodzielność i niezależność organu, który definiujemy jako organ ochrony prawnej. Obowiązujące rozwiązanie w istotny

48 Z uzasadnienia postanowienia TK z dnia 11 kwietnia 2007 roku, K 2/07.

$49 \mathrm{Z}$ uzasadnienia wyroku TK z dnia 21 lutego $2001 \mathrm{roku}, \mathrm{P}$ 12/00, z odwołaniem się do P. Winczorka, Komentarz do Konstytucji Rzeczypospolitej Polskiej, Warszawa 2000, s. 19.

50 Zgodnie z treścią art. 1 ustawy o Państwowej Inspekcji Pracy „organem powołanym do sprawowania nadzoru i kontroli przestrzegania prawa pracy, w szczególności przepisów i zasad bezpieczeństwa i higieny pracy, a także przepisów dotyczących legalności zatrudnienia i innej pracy zarobkowej w zakresie określonym w ustawie". 
sposób różni się od tych, które definiują pozycję Prezesa Najwyższej Izby Kontroli, Rzecznika Praw Obywatelskich, Rzecznika Praw Dziecka czy nawet Prezesa Urzędu Ochrony Danych Osobowych (w tym ostatnim wypadku jest to również organ, którego nie wymienia się w Konstytucji RP). Możliwość odwołania Głównego Inspektora Pracy przez Marszałka Sejmu ${ }^{51}$ w każdym czasie, bez jednoczesnego ustawowego i enumeratywnego sprecyzowania przesłanek uzasadniających takie działanie, jest dowodem na ułomność przyjętego rozwiązania ${ }^{52}$.

Po drugie, zbyt ograniczone są gwarancje niezależności działania organów inspekcji. Widoczny w tym zakresie staje się brak rozwiązań, które konkretyzowałyby choćby ograniczoną postać immunitetu formalnego i które zabezpieczałyby odpowiednią jakość pracy inspektora. Braku tego w żaden sposób nie rekompensuje wymóg niezależności od jakichkolwiek wpływów postronnych i zakaz uczestniczenia w interesach podmiotów kontrolowanych (art. 44 ust. 2 ustawy). Zakaz prowadzenia działalności politycznej (art. 47 ust. 1 ustawy), jak również podejmowania zajęć zarobkowych bez uprzedniej zgody Głównego Inspektora Pracy definiują klasyczne standardy funkcjonowania rzetelnej, bezstronnej i apolitycznej służby, ale dla ochrony praw samego inspektora są niewystarczające.

Po trzecie, co w istotny sposób wiąże się z poprzednią uwagą, w ciągu ostatnich kilkunastu lat zakres obowiązków (zadań i kompetencji) Państwowej Inspekcji Pracy został bardzo rozbudowany. Można nawet odnieść wrażenie, że ze względu na problemy rynku pracy każda związana z tym kwestia stawała się przedmiotem reakcji ustawodawcy, który bez większej refleksji wskazywał Państwową Inspekcję Pracy jako organ właściwy do sprawowania nadzoru i kontroli w zakresie wprowadzanych modyfikacji systemu rozwiązań prawnych w obszarze stosunków pracowniczych i quasi-pracowniczych. W praktyce doprowadziło to do powstania swoistej hybrydy zadań i towarzyszących im kompetencji oraz obowiązków Państwowej Inspekcji Pracy ${ }^{53}$. Istotne przy tym staje się to, że obecnie

51 Nie ma znaczenia gwarancyjnego to, że odwołanie takie może nastąpić dopiero po zasięgnięciu opinii Rady Ochrony Pracy i właściwej komisji sejmowej. Opinia w tym zakresie nie jest dla Marszałka Sejmu wiążąca.

52 O tym, jak jest to ważne, może świadczyć przykład kadencji Przewodniczącego i członków Krajowej Rady Radiofonii i Telewizji. Trybunał Konstytucyjny w swym orzeczeniu wskazał, że zakaz odwoływania członków tego organu ,przed upływem kadencji poza przypadkami wyraźnie przewidzianymi w ustawie, jest gwarancją ich niezależności” - uchwała Trybunału Konstytucyjnego z 10 maja 1994 roku, W 7/94, a także wyrok TK z dnia 13 grudnia 2016 roku, K 13/16. Rozwiązanie to jest tym bardziej dysfunkcjonalne, jeżeli weźmiemy pod uwagę, że ustawa definiuje kadencję Rady Ochrony Pracy (art. 7 ust. 2 ustawy). Nie ma przy tym znaczenia, czy organem centralnym zgodnie z art. 4 ust. 1 Konwencji nr 81 z dnia 11 lipca 1947 roku dotyczącej inspekcji pracy w przemyśle i handlu, Dz.U. z 1997 r. Nr 72, poz. 452 jest Sejm, czy też inny organ, na przykład władzy wykonawczej, zob. więcej D. Makowski, op. cit., s. 47-50.

53 Chodzi tu o zmiany związane z uchwaleniem ustaw: z dnia 4 października 2018 roku o pracowniczych planach kapitałowych, Dz.U. z 2018 r. poz. 2215 (art. 127); z dnia 15 czerwca 2018 roku o zmianie ustawy o systemach oceny zgodności i nadzoru rynku oraz niektórych innych ustaw, Dz.U. z 2018 r. poz. 1338 (art. 8); z dnia 10 stycznia 2018 roku o ograniczeniu handlu w niedziele 
bardziej uzasadnione staje się twierdzenie, iż Państwowa Inspekcja Pracy zbliża się do organu o charakterze policyjnym, aniżeli organu ochrony i kontroli prawa. Co nie mniej istotne, zwiększenie zakresu zadań i obowiązków nie przekłada się na znaczny wzrost zaplecza technicznego, którego istnienie zapewniałoby odpowiednią obsługę dla organów Inspekcji. Przyjęty już dawno model przeprowadzania inspekcji sprowadza więc inspektora do swoistego rodzaju „fenomenu”, który łączy w zakresie swojej działalności zadania i czynności szkoleniowe (edukacyjne), prewencyjne, policyjne (operacyjne), quasi-prokuratorskie, jak również rozstrzygające (władcze). W praktyce mamy więc do czynienia z ,wielofunkcyjnym spektrum kompetencyjnym”, z którym jego dysponent (inspektor) ma się uporać w granicach czasowych wskazanych w ustawie (art. 58).

Po czwarte, sprawne wywiązywanie się z nałożonych zadań powinno wymagać od ustawodawcy wzmocnienia systemowej pozycji Inspekcji i inspektorów w celu rzeczywistego zagwarantowania respektowania konstytucyjnych wolności i praw jednostki (nie tylko samego pracownika, a co za tym idzie — wolności i praw pracowniczych), a także przedsiębiorców (pracodawców), co musi mieć przełożenie na istotę i cel działalności Państwowej Inspekcji Pracy ${ }^{54}$. Powinno to

i święta oraz w niektóre inne dni, Dz.U. z 2018 r. poz. 305 (art. 15); z dnia 7 kwietnia 2017 roku o zmianie ustawy o zatrudnianiu pracowników tymczasowych oraz niektórych innych ustaw, Dz.U. z 2017 r. poz. 962 (art. 6); z dnia 22 lipca 2016 roku o zmianie ustawy o minimalnym wynagrodzeniu za pracę oraz niektórych innych ustaw, Dz.U. z 2016 r. poz. 1265 (art. 6); z dnia 22 lipca 2016 roku o zmianie ustawy - Prawo energetyczne oraz niektórych innych ustaw, Dz.U. z 2016 r. poz. 1165 (art. 11); z 10 czerwca 2016 roku, o delegowaniu pracowników w ramach świadczenia usług, Dz.U. z 2016 r. poz. 868 (art. 9 n.); z dnia 29 kwietnia 2016 roku o zmianie ustawy o promocji zatrudnienia i instytucjach rynku pracy, ustawy o Państwowej Inspekcji Pracy oraz ustawy o wdrożeniu niektórych przepisów Unii Europejskiej w zakresie równego traktowania, Dz.U. z 2016 r. poz. 691 (art. 2); z dnia 13 kwietnia 2016 roku o systemach oceny zgodności i nadzoru rynku, Dz.U. z 2016 r. poz. 542 (art. 109); z dnia 15 stycznia 2015 roku o zmianie ustawy o organizmach genetycznie zmodyfikowanych oraz niektórych innych ustaw, Dz.U. z 2015 r. poz. 277 (art. 12), jak również 15 innych zmian ustawowych (w sumie 27), które miały miejsce w okresie ostatnich 12 lat. Zob. też Sprawozdanie z działalności Państwowej Inspekcji Pracy z 2017 r., https://www.pip.gov.pl/pl/f/v/192642/ Sprawozdanie\%20z\%20dzialalnosci\%20PIP\%20w\%202017.pdf (dostęp: 15.05.2019). Wskazuje się, że w 2017 roku w wyniku działalności PIP „doszło do m.in. likwidacji bezpośrednich zagrożeń dla życia lub zdrowia 77,1 tys. osób; 15,8 tys. powiadomień innych organów o stwierdzonych nieprawidłowościach; 328 szkoleń dla pracodawców z branż o szczególnie wysokim poziomie ryzyka zawodowego 2,2 tys. pracodawców uczestniczących w programach prewencyjnych PIP”.

54 Aktualny, a może nawet dodatkowo uzasadniony staje się pogląd, zgodnie z którym „W ustawie o PIP można dostrzec zakłócenie relacji między funkcjami państwa służącymi ochronie pracy a warunkami ograniczenia wolności i praw konstytucyjnych. Treść niektórych rozwiązań instytucji prawnych w ustawie, liczny wybór środków oddziaływania organów inspekcji, będących w ich dyspozycji skłania do refleksji, że w procesie legislacyjnym nad ustawą ustawodawca położył nacisk tylko na wymiar i poziom obciążeń nakładanych na podmioty kontrolowane. Przy konstruowaniu ustawy ustawodawca w zbyt małym stopniu uwzględnił, że nakładanie przez państwo dolegliwości na podmioty kontrolowane — z punktu widzenia Konstytucji RP — powinno cechować zachowanie zasad racjonalności, praworządności i proporcjonalności w stosowaniu środków" T. Niedziński, op. cit., s. 14-15. 
oznaczać uwzględnienie faktu, że samo rozszerzanie katalogu zadań i obowiązków bez jednoczesnego rozbudowania zaplecza administracyjnego (osobowego) ${ }^{55}$ nie może przełożyć się na zwiększenie efektywności i sprawności prowadzonych przez Państwową Inspekcję Pracy działań znajdujących umocowanie w treści art. 10 i 11 ustawy.

Po piąte, mając na względzie powyższe, może warto byłoby się zastanowić nad zmianą struktury Państwowej Inspekcji Pracy. Postulat większej decentralizacji, który formułowany był ponad 10 lat temu, wydaje się cały czas aktualny. Zakres i charakter zadań nałożonych na Inspekcję wydaje się uzasadniać tego rodzaju ingerencję ustawodawcy ${ }^{56}$.

Po szóste, konieczne byłoby wzmocnienie ochrony tajemnicy kontrolerskiej na kształt tej, która funkcjonuje na gruncie ustawy o Najwyższej Izby Kontroli ${ }^{57}$,jak również uszczegółowienie regulacji ustalającej zakres ochrony interesów przedsiębiorcy (tajemnica przedsiębiorcy) w kontekście realizacji uprawnień kontrolera.

Po siódme, ciekawe jest to, że w ustawie o zmianie niektórych ustaw w związku z zapewnieniem stosowania rozporządzenia Parlamentu Europejskiego i Rady (UE) 2016/679 z dnia 27 kwietnia 2016 roku w sprawie ochrony osób fizycznych w związku z przetwarzaniem danych osobowych i w sprawie swobodnego przepływu takich danych oraz uchylenia dyrektywy 95/46/WE (ogólne rozporządzenie o ochronie danych) ${ }^{58}$ nie odniesiono się do funkcjonowania Państwowej Inspekcji Pracy i jej organów. Pominięcie to przy jednoczesnej zmianie innych regulacji ustawowych ${ }^{59}$ może w praktyce nastręczać istotnych problemów na płaszczyźnie realizacji praw przez osoby, których dane będą przez Inspekcję przetwarzane.

55 Zgodnie ze sprawozdaniem z 2015 roku w PIP zatrudnionych było — według stanu na dzień 31.12.2015 roku - 2768 osób, Sprawozdanie z działalności Państwowej Inspekcji Pracy w 2015 roku, s. 10 (https://www.pip.gov.pl/pl/f/v/156451/Sprawozdanie\%202015.pdf [dostęp: 15.05.2019]). W listopadzie 2017 roku natomiast wskazywano: „Rada zwróciła uwagę, że w budżecie PIP na 2018 r. zaplanowano 4 proc. wzrost wynagrodzeń dla pracowników Inspekcji. W przyszłorocznym budżecie mają się też znaleźć pieniądze na większą liczbę etatów. Docelowo ma ona wynosić 2 tys. 836." - Państwowa inspekcja Pracy zwiększy zatrudnienie, https://www.pulshr.pl/rekrutacja/panstwowa-inspekcja-pracy-zwiekszy-zatrudnienie,48418.html (dostęp: 15.05.2019). Por. też Sprawozdanie z działalności Państwowej Inspekcji Pracy z 2017 r., Warszawa 2018, https://www.pip.gov.pl/ pl/f/v/192642/Sprawozdanie\%20z\%20dzialalnosci\%20PIP\%20w\%202017.pdf(dostęp: 15.05.2019).

56 „Tworzenie mniejszych terytorialnie jednostek organizacyjnych inspekcji pracy obok dotychczas działających oddziałów PIP, związanych z podziałem terytorialnym okręgowych inspektoratów pracy mogłoby się odbyć w ramach decentralizacji organów inspekcji pracy na wzór decentralizacji administracji publicznej. Powyższe rozwiązanie organizacyjne pozwoliłoby zwiększyć ilość mniejszych terytorialnie jednostek organizacyjnych inspekcji pracy w okręgowych inspektoratach pracy" - T. Niedziński, op. cit., s. 16.

57 Chodzi tu o gwarancje zawarte w art. 28a ust. 3 i 73 ustawy z dnia 23 grudnia 1994 roku o Najwyższej Izbie Kontroli, tekst jedn. Dz.U. z 2019 r. poz. 489.

58 Ustawa z dnia 21 lutego 2019 roku, poz. 730.

59 Np. ustawy z dnia 20 kwietnia 2004 roku o promocji zatrudnienia i instytucjach rynku pracy, Dz.U. z 2018 r. poz. 1265 ze zm. 


\section{PODSUMOWANIE}

Analiza pozycji ustrojowej tak złożonego organu, jakim jest Państwowa Inspekcja Pracy, może oczywiście opierać się na wielu różnych przesłankach. Pomocne są także te, które wyznaczają standardy niezależności najwyższych organów kontroli ${ }^{60}$. Specyfika działalności Państwowej Inspekcji Pracy pozwala bowiem na takie porównanie, choć, jak wskazywałem wcześniej, organ ten nie ma w naszym porządku prawnym statusu konstytucyjnego. Wydaje się, że właśnie ten fakt ma istotne znaczenie dla wypracowania aktualnego modelu organizacji i funkcjonowania Państwowej Inspekcji Pracy, także przez pryzmat rozwiązań funkcjonujących w okresie ostatnich stu lat.

Przedstawione w opracowaniu uwagi kierowane są przede wszystkim do ustawodawcy, którego rola nie powinna sprowadzać się jedynie do rozszerzania zadań Państwowej Inspekcji Pracy, ale do systemowej analizy roli tego organu w polskim systemie prawno-ustrojowym. Działalność prawodawcy krajowego powinna też uwzględniać fakt, że dobre imię i ocenę działalności konkretnej instytucji budują osoby (funkcjonariusze) ją reprezentujące oraz adresaci działań przez nich podejmowanych. Podstawą sprawnej i rzetelnej działalności staje się więc przede wszystkim takie wyważenie instrumentów prawnych, które z jednej strony zapewni funkcjonowanie należycie zorganizowanej i w pełni neutralnej służby, z drugiej zaś poczucie, że służba ta ma na celu rzeczywistą ochronę wolności i praw konstytucyjnie gwarantowanych.

\section{THE PLACE OF THE NATIONAL LABOUR INSPECTORATE IN THE SYSTEM OF STATE AUTHORITIES - DE LEGE LATA AND DE LEGE FERENDA REMARKS}

\section{Summary}

The fundamental issue raised in this elaboration comes down to an attempt at defining the character and content of labour protection and the place of the National Labour Inspectorate in the system of state authorities in Poland. The analysis relates to the applicable constitutional regulation (Constitution of the Republic of Poland of 2 April 1997) and statutory regulations. The purpose of the considerations is to determine the nature of the activity of the National Labour Inspectorate as well as its location within the constitutional systematizations.

Keywords: National Labour Inspectorate, work, human rights, Polish constitution, labour protection, law enforcement authority, respect for constitutional freedoms and rights of the individual

${ }^{60}$ Zob. więcej M. Serowaniec, Konstytucyjne gwarancje niezależności najwyższych organów kontroli w państwach członkowskich UE, Toruń 2018, s. 90 n. 


\section{BIBLIOGRAFIA}

Balicki R., Bezpośrednie stosowanie Konstytucji, „Krajowa Rada Sądownictwa” 2016, nr 4.

Banaszak B., Konstytucja Rzeczypospolitej Polskiej. Komentarz, Warszawa 2009.

Bernaczyk M., Pojęcie publicznych praw podmiotowych w świetle Konstytucji RP, [w:] Wolności $i$ prawa jednostki $w$ Konstytucji $R P$, t. 1. Idee i zasady przewodnie konstytucyjnej regulacji wolności i praw jednostki w RP, red. M. Jabłoński, Warszawa 2010.

Demenecki T., Bodio J., Borkowski G., Ustrój organów ochrony prawnej. Część szczegółowa, Warszawa 2015.

Garlicki L., Uwagi do art. 24, [w:] Konstytucja Rzeczypospolitej Polskiej. Komentarz, t. 5, red. L. Garlicki, Warszawa 2003.

Horyzontalne oddziatywanie Konstytucji Rzeczypospolitej Polskiej oraz Konwencji o Ochronie Praw Człowieka i Podstawowych Wolności, (,,Studia i Materiały Trybunału Konstytucyjnego" 56), red. A. Młynarska-Sobaczewska, P. Radziewicz, Warszawa 2015.

Izdebski H., Zarzadzanie etyka za pośrednictwem kodeksów etyki zawodowej, [w:] Etyka w stużbie publicznej, red. J. Czaputowicz, Warszawa 2012.

Jagielski J., Kontrola administracji publicznej, Warszawa 2007.

Jarosz-Żukowska S., Charakter i znaczenie wolności i praw jednostki wyrażonych w rozdziale I Konstytucji RP, [w:] Wolności i prawa jednostki w Konstytucji RP, t. 1. Idee i zasady przewodnie konstytucyjnej regulacji wolności i praw jednostki w RP, red. M. Jabłoński, Warszawa 2010.

Jarosz-Żukowska S., Horyzontalne działanie praw człowieka w sferze stosunków pracowniczych w świetle Konstytucji RP, [w:] Horyzontalne oddziatywanie Konstytucji Rzeczypospolitej Polskiej oraz Konwencji o Ochronie Praw Człowieka i Podstawowych Wolności, (,Studia i Materiały Trybunału Konstytucyjnego 56"), red. A. Młynarska-Sobaczewska, P. Radziewicz, Warszawa 2015.

Kiczka K., Krajowy organ administracji publicznej w prawie unijnym, Wrocław 2013.

Kuczma P., Prawa pracownicze, [w:] Realizacja i ochrona konstytucyjnych wolności i praw jednostki w polskim porzadku prawnym, red. M. Jabłoński, Wrocław 2014.

Kuczma P., Prawo do pomocy spotecznej, [w:] Realizacja i ochrona konstytucyjnych wolności i praw jednostki w polskim porzadku prawnym, red. M. Jabłoński, Wrocław 2014.

Kuczma P., Prawo do zabezpieczenia spotecznego, [w:] Realizacja i ochrona konstytucyjnych wolności i praw jednostki w polskim porządku prawnym, red. M. Jabłoński, Wrocław 2014.

Lang J., Rozważania nad prawnym położeniem Państwowej Inspekcji Pracy, Wrocław 1999.

Liszcz T., Państwowa Inspekcja Pracy — strażnik praworzadności w stosunkach pracy, „Kontrola Państwowa" 2006, nr 3.

Łukaszczuk A., Prawo dostępu do stużby publicznej, [w:] Realizacja i ochrona konstytucyjnych wolności i praw jednostki w polskim porządku prawnym, red. M. Jabłoński, Wrocław 2014.

Makowski D., Pozycja prawna Państwowej Inspekcji Pracy, „Państwo i Prawo” 2010, nr 3.

Muszalski W., Państwowa Inspekcja Pracy, „Przegląd Ustawodawstwa Gospodarczego” 1981, nr $10-12$.

Niedziński T., Opinia prawna na temat: Prawno-ustrojowy status Państwowej Inspekcji Pracy a skuteczność jej działania w świetle obecnych rozwiąań krajowych i europejskich, Kancelaria Senatu Biuro Informacji i Dokumentacji, Dział Analiz i Opracowań Tematycznych, Opinie i Ekspertyzy OE-84, październik 2008.

Proces prawotwórczy w świetle orzecznictwa Trybunału Konstytucyjnego. Wypowiedzi Trybunału Konstytucyjnego dotyczace zagadnień zwiąanych z procesem legislacyjnym, Warszawa 2015.

Rojewski M., Organy ochrony prawnej. Orzecznictwo, Warszawa 2011.

Rzucidło J., Krajowa Rada Radiofonii i Telewizji jako konstytucyjny organ ochrony wolności słowa i prawa do informacji w radiofonii i telewizji, [w:] Realizacja i ochrona konstytucyjnych wolności i praw jednostki w polskim porządku prawnym, red. M. Jabłoński, Wrocław 2014. 
Serafin S., Szmulik B., Organy ochrony prawnej RP, Warszawa 2007.

Serowaniec M., Konstytucyjne gwarancje niezależności najwyższych organów kontroli w państwach członkowskich UE, Toruń 2018.

Sokolewicz W., Komentarz do art. 7 Konstytucji RP, [w:] Konstytucja Rzeczypospolitej Polskiej. Komentarz, t. 2, red. L. Garlicki, Warszawa 2003.

Sprawozdanie z działalności Państwowej Inspekcji Pracy z 2017 r., https://www.pip.gov.pl/pl/f/v/ 192642/Sprawozdanie\%20z\%20dzialalnosci\%20PIP\%20w\%202017.pdf.

Winczorek P., Komentarz do Konstytucji Rzeczypospolitej Polskiej, Warszawa 2000.

Witkowski Z., Bień-Kacała A., O potrzebie redefinicji terminu ,organ państwa”, [w:] W stużbie dobru wspólnemu. Księga Jubileuszowa dedykowana Profesorowi Januszowi Trzcińskiemu, red. R. Balicki, M. Masternak-Kubiak, Warszawa 2012. 